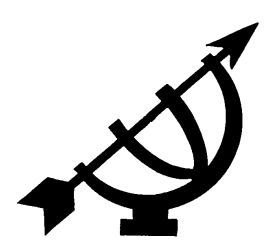

\title{
Atomism and holism in the understanding of society and social systems
}

\author{
D.F.M. Strauss \\ Faculty of Human Science \\ University of the Free State \\ BLOEMFONTEIN \\ E-mail:dfms@cknet.co.za
}

\begin{abstract}
Atomism and holism in the understanding of society and social systems

Throughout its history, reflection on human society has been torn apart by the opposing views of atomism and holism. Traditional societies, the city state of ancient Greece as well as the medieval perfect society apparently resemble a whole with its parts. Early modernity continued this holistic inclination for a while, but soon reverted to atomistic theories of the (hypothetical) social contract. Modern humanism dominated the subsequent views articulated in terms of the dialectical tension between nature and freedom (science ideal and personality ideal) - including mechanistic and vitalistic approaches as well as the more recent acknowledgment of irreducibly complex systems (Behe, 2003). In Wiener's (1954; 1956) "technologicism" human responsibility and freedom are sacrificed. An alternative view is advanced in terms of the normativity of societal life as well as its many-sidedness. It is shown that theories of social systems increasingly tend to explore avenues transcending the limitations of the atomistic additive approach and the boundary-leveling whole-parts scheme entailed in social systems theory. This development is used as a starting point for the classification of social interaction and for underscoring the scope of the principle of sphere-sovereignty for a multidisciplinary understanding of social systems.
\end{abstract}




\section{Opsomming}

\section{Atomisme en holisme in die verstaan van die samelewing en sosiale stelsels}

Dwarsdeur die geskiedenis tref ons teenstellende opvattings oor die menslike samelewing aan, naamlik atomistiese en holistiese sienings. Tradisionele samelewings, die stadstaat van antieke Griekeland asook die middeleeuse perfekte samelewing, vertoon skynbare ooreenkomste met 'n geheel en die dele daarvan. Die vroeg-moderne tyd het hierdie holistiese geneigdheid voortgesit, maar het spoedig oorgeslaan na atomistiese teorieë van 'n hipotetiese sosiale verdrag. In die daaropvolgende tydperk was die opvattings van die Humanisme dominant. Dit het gestalte aangeneem in die spanning wat na vore gekom het tussen natuur en vryheid (natuurwetenskapsideaal en persoonlikheidsideaal). Die Humanistiese erfenis het 'n tuiste gebied vir meganistiese- sowel as vitalistiese benaderings asook vir die meer resente erkenning van onherleibaar-komplekse stelsels (Behe, 2003). Wiener (1954; 1956) se "tegnologisisme" het die mens se verantwoordelikheid en vryheid opgeoffer. In 'n alternatiewe siening word aandag gegee aan die normatiwiteit van die menslike samelewing terwyl daar ook gelet word op die veelsydigheid daarvan. Daar word aangetoon dat sosiale sisteemteorieë toenemend daartoe neig om weë te ondersoek waarlangs 'n mens die beperkings van die atomistiese optelsombenadering asook die grensuitwissende geheel-deleskema van die holisme te bowe kom. Hierdie ontwikkeling word gebruik as aanknopingspunt vir die klassifikasie van vorms van sosiale interaksie asook vir 'n beklemtoning van die reikwydte van die beginsel van soewereiniteit-in-eie-kring vir 'n multidissiplinêre verstaan van sosiale stelsels.

\section{Orientation}

Humankind is known to have lived in societies since the dawn of history. It is therefore not surprising that the emergence of theoretical reflection on the human predicament was accompanied by attempts to portray the best way of living together and the best way to understand what is entailed in the good (societal) life.

The history of theoretical reflection upon the nature of human society diverges into two mutually exclusive (and often opposing) modes of explanation, an atomistic and a holistic one. Although both these approaches were already present in ancient Greece - where 
the atomism (individualism) ${ }^{1}$ of Callicles was opposed by the eventual holism (universalism) of Plato (advanced in his Politeia - Books 4 to 8, 1966) and Aristotle (in his Politics, 1894: 1, 149-150; 1253 a $19 \mathrm{ff}$.) - traditional societies appear to be close to a holistic perspective. The extended family (German: Großfamilie), sib and clan as well as the politically stronger organised tribe, are all examples of close-knit social practices where it is the whole that acts in various capacities, be it as a farming (agricultural), political or cultic unit.

In ancient Greece the undifferentiated patrician clans were the bearers of power within the Greek city states (the polis). The latter took on diverse forms but within them the popular assembly of free citizens assumed a position of power. In the course of its further development the polis ended the dominance of the clans, tribes and brotherhoods in replacing the initial four Ionian tribes with ten new territorial tribes. This provided the basis for the well-known Athenian democracy that reached its peak under Pericles (446-404 BC). Soon after the end of the Persian wars the reign of Pericles came to a fall. During the golden fifth century $\mathrm{BC}$ the transition from the older undifferentiated clans and tribes to the relatively more differentiated legal order of the polis was witnessed.

While the prepolis period was still strongly influenced by conceptions of dikè and themis (the internal legal order of the clans) as the guardian of the natural order of things, the fifth century witnessed significant new developments. Dikè now designated the positive law formed by the polis and the punishment exercised by virtue of these positive laws. On the basis of his conception of a threefold soul, Plato then developed a theory of justice in the form of his utopian view of the state, constituted by the (lowest) artisan class, the (intermediate) warrior class and the (ruling) class of philosopher kings (50 years and older). The qualification utopian must be coupled with another characteristic feature, namely its all-encompassing, totalitarian focus. Furthermore, justice is seen as a moral virtue assigning to the virtues of temperance, courage and wisdom each their place. The ideal state is destined to achieve moral goodness - a view continued by Aristotle in his teleological understanding according to which society develops from the family (as germ cell) via the village to the state, having as its goal moral perfection.

1 Atomism and holism attempt to explain the universe in terms of a discrete multiplicity of basic entities (atoms). Holism, by contract, proceeds from some or other whole, encompassing whatever else there is as mere parts. 
During the Medieval era this view was subordinated to the supra natural realm of grace - moral perfection is the natural portal of the supranatural position of the church as perfect institute of grace, having eternal bliss as its final goal. The initial ideal of a perfect society was thus incorporated in the Roman Catholic view of the Corpus Christianum as the societas perfecta. When the power of the Roman Catholic church reached its peak under Pope Boniface VIII at the beginning of the fourteenth century, it served as a relatively differentiated superstructure over-arching a relatively undifferentiated substructure. Both the guild system and the feudal order preceded the subsequent differentiation of Western society.

At the time of the Renaissance, early modernity was acquainted with the inclination to contemplate an ideal society. When Thomas Moore published his Utopia in 1516 he simply continued this long-standing inclination. Moore, on the one hand, criticises existing society and alternatively portrays a perfect life without private ownership, centered in a market-place. The peculiarly new feature of the modern era specifically surfaces in Bacon's New Atlantis for in it we find a starting-point of the modern ideal that believes that a science directed towards the pure facts will be able to liberate humankind from its burdens. This eventually turned into an essential part of the enlightenment progress ideal.

However, this science ideal soon turned utopian thinking upside down. Instead of contemplating an ideal not found in the empirical world, it sets out to break down reality theoretically (i.e. by means of a thought experiment) in order to reconstruct a new world according to the plan of human reason. Hobbes (1968) explicitly explored the possibilities of such a thought experiment. In his work on material things he first demolished the ordered world into a heap of chaos and then, by using well-defined concepts, reconstructed it from rational resources. Applied to human society this resulted in the early modern theories of the social contract (Hobbes, Pufendorff, Thomasius and Locke). The natural science ideal proceeded in an atomistic fashion, and extending its claims to the realm of human society entailed that the atoms of society, namely the individuals, should now be used as building blocks in the rational construction of society. This is a hypothetical account of the emergence of an ordered society. Initially this atomistic approach served theories of the power-state (which is both absolutistic and totalitarian - such as defended by Hobbes who claims that the social contract empowered the monarch to everything - see Hobbes, 1968:230), the state as Leviathan not acknowledging any limits to its power. 
However, the initial driving force behind the natural science ideal is found in the Renaissance motive of autonomous freedom. It was only in order to proclaim this freedom that an instrument was required and the ideal of an all-encompassing natural scientific analysis (in mathematical-mechanical-physical terms) provided such an instrument, considered to support the enthronement of the personality ideal. 2 Unfortunately this instrument turned out to contain the largest threat to its creator, because the mere idea that everything in the universe is subject to exact natural laws ultimately eliminates all human freedom. Those who were in the grip of the science ideal and thought of the future of society, became victims of a totalitarian view according to which everything could be mastered and controlled, envisaging also human society according to a fixed and predetermined pattern. 3

During the nineteenth and early twentieth centuries we find new dominant principles of explanation entering the scene, although their core meaning already surfaced in Greek philosophy. This is particularly the case regarding the opposition of constancy and change - an opposition underlying the claim of Heraclitus that one can never step into the same river twice. The physicalist atomism (also known as materialism) of some enligthenment thinkers was challenged by the focus on the organic during the Romantic period (late eighteenth and early nineteenth centuries). It was during this period that the rationalistic atomism of the Enlightenment made room for the ideology of the community, proceeding from an irrationalistic 4 and holistic perspective. The rationalistic ethics of Kant sacrificed individuality to the universally valid law-giving entailed in the categorical

2 When Edmund Husserl portrays the development of modern philosophy he characterises its "rationalistic science-ideal" (Husserl, 1954:119). His contemporary, Georg Simmel, used the expression "personality ideal" (see Lotter, 2000:188). According to Dooyeweerd one can view nature (science ideal) and freedom (personality ideal) as the basic motive or groundmotive of modern (humanistic) philosophy (Dooyeweerd, 1997-1:200 ff., 216 ff.).

Both Huxley's The Brave New World (1932) and Orwell's 1984 (published in 1948) continued to portray an encompassing stable community solely guided by a concern for the self - although Orwell ultimately sacrifices freedom to the power of the elite (the tyranny of a powerstate; see Van Riessen, 1952:58-67).

One may define rationalism as an epistemological position overemphasising universality and irrationalism as overaccentuating individuality. Dooyeweerd identified the law for and the lawfulness of reality and therefore he mistakenly thought that rationalism and irrationalism respectively absolutises the law side and factual side of reality. 
imperative, whereas Romanticism claimed that each individual, and eventually each organic community (nation) is a law unto itself. Later on Darwin reverted to an extreme form of physicalism in his 1859 work (cf. Strauss, 2007). The rise of neo-Vitalism during the end of the nineteenth century and the beginning of the twentieth century once again continued to impose the difference between physicalistic and organicistic approaches upon views of human society - still accompanied by the opposition between atomism and holism.

The incredibly complex nature of living entities more recently - once again a century later - inspired considerations concerning the structural plan (German: Bauplan) of living things, particularly advanced by Behe in his idea of irreducibly complex systems (cf. Behe, 2003:39 ff.). 5

With his specific understanding of information as the reverse of entropy - the one is simply the opposite of the other (Wiener, 1950:18) - Wiener introduced his new discipline of cybernetics. His understanding of information is closely connected to communication and since sociology and anthropology are basically sciences of communication they are considered to be parts of cybernetics. Yet he orients himself to physics and logical positivism (Wiener, 1964: 89) as well as to pragmatism. This explains why he holds that words such as "life, purpose, and soul are grossly inadequate to precise scientific thinking" (Wiener, 1954:31). He therefore advises that it is best "to avoid all question-begging epithets such as 'life', 'soul', 'vitalism', and the like". There is no reason why "machines" may not "resemble human beings in representing pockets of decreasing entropy in a framework in which the large entropy tends to increase" (Wiener, 1954:32).

What used to be seen as a unique feature of living entities, their constant exchange of materials (already in ancient Greece connected to fire as the symbol of life), is merely a characteristic of thermodynamically open systems (just recall Von Bertalanffy's (1973:149) generalisation of the second main law to open systems). It therefore does not contradict Wiener's physicalistic inclination to highlight an open system when he says: "We are but whirlpools in a river of ever-flowing water. We are not stuff that abides, but patterns that perpetuate themselves." (Wiener, 1954:96.)

5 Sussenbach (2005:138) supports this idea of Behe and explains celldivision as an example of an irreducibly complex system. 
Since Wiener equates the human person with cybernetic machines and identify information with structure (pattern) his physicalistic fantasy truly envisages what, according to him, it is in principle (although currently not practically executable) highly plausible: "In other words, the fact that we cannot telegraph the pattern of a man from one place to another seems to be due to technical difficulties, ... The idea itself is highly plausible" (Wiener, 1954:104).

His combination of communication and control, combined with his mentioned comparison of machines and human beings, underscores the ultimate physicalistic determinism present in his thought, in principle eliminating human freedom. Schuurman is therefore justified in his critical stance towards Wiener. He rejects the equation of entropy and information for it is only through technological formation that the physical energy-structure can become information (Schuurman, 2008:185). In this way energy becomes structured energy, such as in signals - and this leads him to the conclusion that "[i]nformation theory is really the theory of signal transmission" (Schuurman, 2008:392). According to him

[p]hysical energy is the basis for information conceived as the analytical substratum of language. The transporting of information - communication - is a total event in which the lingual object function retrocipates, via the analytical function, on the energy function (Schuurman, 2008:186).

With his ultimate concern for "mechanical control" Wiener's "philosophy is a form of technologism" (Schuurman, 2008:205). Human responsibility and freedom are not accounted for.

\section{The matrix of normativity in human society}

When the accountable human freedom to respond to normative principles is acknowledged, human society can be appreciated in terms of modes of explanation exceeding the one-sidedness entailed in atomistic, holistic, mechanistic, physicalistic or vitalistic approaches. ${ }^{6}$ A mere focus upon aspects of nature, such as those of number (the point of orientation of atomism), space (the startingpoint of holism), the kinematic (explored by mechanistic views) the physical (distorted by physicalism) cannot furnish us with an insight

6 Note that these five isms find their point of orientation in the following five aspects of reality - respectively the arithmetical, spatial, kinematic, physical and biotic aspects. 
into the normative accountability of human beings. This unique human freedom first of all manifests itself in the normative contraries present in our everyday experience of life, such as those between logical and illogical, kind and hostile, legal and illegal, thrifty and wasteful, beautiful and ugly, polite and impolite.

Without a yardstick, a norm or a principle, it will not be possible to differentiate between what is logical, i.e. conforming to logical principles such as those of identity, non-contradiction, the excluded middle, sufficient reason, thought economy, and so on. Although there may be differences of opinion regarding the nature of these principles it cannot be denied that principles are involved.

The first task of this kind of approach will be to identify the different kinds of normative principles guiding human societal activities. For example, if one considers societal collectivities such as universities, cultural associations, sport clubs, states, or marriages, it is always possible to find a guiding or leading normative perspective. Universities, for example, as academic institutions, are guided by theoreticallogical concerns captured in the idea of scholarship (teaching and doing research). Likewise, states, as public legal institutions, are guided by concerns for public justice, business enterprises by considerations of frugality, i.e. avoiding what is excessive. A tentative list of all the normative aspects of reality is given by the following: the logical-analytical aspect, the cultural-historical aspect, the sign mode, the social facet, the economic function, the aesthetic mode, the jural side, as well as the moral and certitudinal spheres.

It is clear that human beings do function within all these normative aspects, because they are capable of thinking and arguing; of cultural forming and shaping; of speaking, listening and interpreting; of socialising; of acting in frugal, non-excessive ways; of appreciating what is beautiful; in observing the rights of others; in respecting and loving fellow human beings; and in trusting, believing and confiding. Whereas animals experience reality exclusively from their natural inclination, 7 directed at that which is important to them in a physical, biotic and sensitive sense, 8 human beings have the flexible freedom

$7 \quad$ Portmann (1990:79) characterises animals as Umweltgebunden (constrained by environment) and Instinktgesichert (protected by instinct).

8 Animals experience reality in terms of that which is negotiable and not negotiable, edible and inedible, in terms of same sex and opposite sex, comforting and alarming. 
to choose alternative guiding functions for their actions. Since those aspects in which a person typically functions are not instinctively assured or bound, humankind has a flexibility making possible an incredible specialisation in differentiated civilisations. Even Simpson (1969:90) emphasises this: "Such specialization, which is non-genetic, requires individual flexibility and could not occur in a mainly instinctive animal."

Portmann (1974:102) typifies the peculiar human freedom of choice as follows:

The narrow limitations of animal interests is opposed to our freedom of choice and direction. Animals can escape the bonds of their urges only to a limited extent, while I myself can, in every moment, in accordance with my whole attentativeness, turn my entire inwardly participative dedication to some or other matter, however insignificant it may appear to be.

However, human beings functioning within various aspects and under the guidance of particular normative vistas are not isolated individuals, they are organised in diverse social collectivities and these social entities display a unique intertwinement owing to the fact that every human being can assume multiple social roles within themselves, without ever being exhausted by any one of them. Over and above these collective roles, human beings also live out a personal domain of freedom not absorbed by any societal institution. It was particularly the discipline of sociology that accepted the challenge to account for the complexities of human social interaction. An analysis of the history of this discipline reveals a variation of positions in this respect, with the earlier mentioned atomistic and holistic views as extreme opposites.

\section{Basic concepts: an interdisciplinary many-sidedness}

Unfortunately sociological theorising attempted to come to terms with the complexity of human social interaction without explicitly and critically entering into an analysis of the basic concepts involved in its theoretical analyses. The basic concepts I have in mind can be phrased in combined phrases where the qualifying term in each instance designates the perspective of the discipline under consideration - the social. No single sociological theory managed to side-step the implicit or explicit use of the following elementary basic concepts: social order, social stratification, social constancy and dynamics, social differentiation and integration, social sensitivity, soli- 
darity and consciousness, social consensus and conflict, social power and control, and social symbolism, meaning and interpretation. ${ }^{9}$

These elementary basic concepts must be distinguished from true metaphors. Their (implicit or explicit) use proved to serve as the foundation for the widely diverging theoretical designs operative during the past two centuries of sociological theorising. An explicit and articulated account of these elementary basic concepts may enable us to develop an integral perspective on sociology as a discipline. In addition such an analysis will demonstrate that the discipline of sociology evinces an encyclopaedic coherence with all the other academic disciplines, because in each case the second term, qualified by the term social, reflects the meaning of a different aspect of reality serving as point of entry for a distinct special science.

It happens frequently that a particular sociological approach overemphasises a specific basic concept of sociology. Sometimes even a combination of certain elementary basic concepts is overestimated. These privileged basic concepts then serve as the encompassing or root perspective of the theoretical design under consideration. In such a case one or a limited number of basic concepts are removed from their coherence with all the other basic concepts and elevated to the comprehensive level of an all-determining totality or root perspective. In this process many pseudoroots are created. Each such pseudoroot subtly provides an encompassing anchoring for all the other basic concepts covered by its umbrella. Though research shows, for example, that certain concepts are used more frequently by symbolic interactionism than by the structural functional approach, it does not mean that either of these theoretical trends could sidestep the inevitability of using all the elementary basic concepts of sociology. The only difference is that each orientation attaches its own understanding to those elements that do not occupy a central position.

Of course these approaches did see some worthwhile traits in reality but unfortunately distorted the meaning of what they discovered through a one-sided overemphasis. Even the most extreme reductionistic approach, after all, did see something "out there" in reality something all sociological approaches have to account for in their own way.

9 The meaning and coherence of these elementary basic concepts are analysed in detail in Strauss (2006:125-244). 
As we all know the modern scholarly dispensation is characterised by a large number of distinct academic disciplines - basically differentiated in the natural sciences and the humanities. Within the natural sciences perhaps the two most familiar, but also most perplexing realities are found in the nature of matter and the complex nature of living entities ("life" - compare the above-mentioned view of Behe (2003) regarding irreducibly complex systems) - and Wiener (1954:9 ff.; $21 \mathrm{ff}$.) added information as something irreducible to matter (and its equivalent: energy). Within the humanities the reality of complex social (global) systems appear to pose a challenge to a multidisciplinary understanding in which the diverse academic disciplines (special sciences) play their role. A truly complex system cannot be decomposed or reduced to the angle of approach of any distinct special science focusing on it. The modern state or the business enterprise, for example, exceeds the scope of both the disciplines of law and economics, for the simple reason that neither a state nor a firm can be completely reduced to either of these perspectives (aspects) - the economic or the jural.10

Even the most basic concept of physical nature, that of matter, exceeds the grasp of merely one angle of approach; and that in spite of the aim of superstring theory to produce a "theory of everything" it turned out that not even matter could be explained exclusively in physical terms. It is therefore not surprising that Stegmüller (1987) believes that one of the most difficult questions facing science in the twentieth century is indeed given in the concept of matter, which he considers to be mysterious in the utmost sense.

When Stegmüller continues his explanation of the problems attached to an understanding of the nature of matter the most basic aspects of empirical reality surface. In the first place he distinguishes two global basic conceptions regarding the nature of matter and he points out that currently these conceptions once again, as previously, occupy a prominent place in the discussions. He calls these two basic conceptions the atomistic conception and the continuity conception. ${ }^{11}$ Also Laugwitz (1986) points out that insofar as phy-

10 Note that what we have in mind here is the ontic nature of these aspects. Once the jural takes on positive forms within statelaw, for example, the term juridical is applicable.

11 "Selbst die beiden großen Grundkonzepte über die Natur der Materie stehen heute nach wie vor zur Diskussion, wenn auch mannigfaltig verschleiert hinter Bergen von Formeln. Diese beiden Grundkonzepte kann man als die 
sics subjects itself to auxiliary means from mathematics, it cannot escape from the polarity between continuity and discreteness. ${ }^{12}$

As we noted the opposing extremes of atomistic and holistic approaches in the understanding of nature (physics and biology) are also present within the humanities. One merely has to reflect upon the connection and difference between the biotic aspect and the social aspect of reality. Without any doubt there are marked similarities between biotic phenomena and the structure and functioning of human society. Certain sociological trends of thought were so impressed by these similarities that they viewed social phenomena as living organisms - thus neglecting the differences between social phenomena and biotic phenomena. Of course this theoretical approach could manifest itself in multiple ways. It includes the social theories of Aristotle, Thomas Aquinas, Hegel, Comte, Spencer, Spann, Wiener, Parsons, Von Bertalanffy, Buckley, Alexander and Münch - to recall a few. Most of these thinkers share the theoretical conviction that society ought to be analysed in terms of a(n organic) whole and its (organic) parts. This is what we designated as a holistic or universalistic approach.

Of course an overemphasis of the biotical analogy within the structure of the social aspect of reality by its very nature contradicts those theoretical approaches which overemphasise other analogical structural moments within the social aspect. Therefore it is insufficient simply to relativise the presence of diverse "schools of sociological thought" since they are genuinely, due to diverging reductionistic perspectives, mutually exclusive. Such a relativising attempt was undertaken by Fletcher (1971a:815 ff.). Waters (1994:345) correctly remarks: "The pleasures of complementarity notwithstanding, theories which contradict one another cannot all be correct or true."

A consistent organicistic holism finds its theoretical opposition in an atomistic individualism according to which all societal entities are mere collections of individuals. Alexander (1987:12) casts this opposition in the following terms: rational-individualistic versus rationalcollectivist. Another way to formulate this dilemma concerns the problems related to action on the one hand and order on the other

atomistische Auffassung und als die Kontinuumsauffassung der Materie bezeichnen." (Stegmüller, 1987:91.)

12 "Die Physik, insofern sie sich mathematischer Hilfsmittel bedient oder sich gar der Mathematik unterwirft, kann an der Polarität von Kontinuierlichem und Diskretem nicht vorbei." (Laugwitz, 1986:9.) 
hand (Alexander, 1987:12). Alexander also speaks of "subjective voluntarism" and "objective constraint" (Alexander, 1987:376). He believes that these problems are not optional: "every theory takes some position on both" (Alexander, 1987:12). Yet, according to him no intellectual tradition can be grounded in conceptions of action alone. We are concerned here with social theories, and every social theory must also be concerned about the problem of order (Alexander, 1988:13-14).

A consistent individualistic or atomistic method of concept formation and research, aims at reducing all societal relationships, processes and collectivities to "individuals-in-interaction". It is opposed to a universalistic or holistic approach. The latter always proceeds from one or other social whole - sometimes plainly designated as "society" or the "social system" and, consequently, assigns a subordinate role to the individual - as being a mere part of this encompassing whole. In various chapters of Hollinger's (1994) work on Postmodernism and the social sciences we find an extensive discussion of two "different models" with their accompanying methods of analysis: the "atomistic model" and the "organic model".

Hollinger points out that the atomistic model, which is derived from Newtonian physics and defended by advocates of the enlightenment, especially by liberals and utilitarians, views society as an aggregation of individuals governed by the laws of nature, particularly the law of the maximisation of one's rational self-interest. The organic model, derived from Plato and Aristotle, is defended by romantics and other counter-enlightenment figures, including many political and cultural conservatives and reactionaries, and also by Marx. In this view, individuals are products of their community and can only realise themselves in it (Hollinger, 1994:5).

\section{A classification of social interaction}

Though one may argue that both these approaches highlight relevant facets of social reality, the one-sided claims they make - to the exclusion of each other - cannot both be maintained at the same time. The first step in overcoming the one-sidedness present in these two opposing approaches is to combine the elementary basic concepts of sociology in a complex analysis of the different ways of social interaction within a differentiated society. This is made possible by the fact that the social aspect of reality can only reveal its meaning through its coherence with all the other aspects, including those preceding the social aspect in the order of aspects. All concrete events in principle function within all aspects of reality, there- 
fore this concrete many-sidedness invites all the academic disciplines to make their distinct contribution to an understanding of social action. If we restrict ourselves first of all to the possible ways in which an account can be given of social interaction, it soon becomes clear that such social interaction cannot be described and classified without "borrowing" terms from non-social aspects. This is already evinced in the expression interaction. The word inter means between and is derived from the meaning of spatial extension and positionality, while the word action comes from the meaning of physical activity. Particularly the physical analogy of thermodynamic open systems enables the conceptual understanding of social phenomena of mutual exchange. The coming and going of individuals do not eliminate the durability (identity) of that specific social relation. Of course incidental social events cannot constitute a durable whole which continues regardless of the exchange of participating social subjects.

Social interaction can occur within a social form of life that is integrated into a genuine whole or totality. Alternatively it can occur on a less rigid basis of standing over against one another or facing one another. The standing alongside or in coordination with fellow human beings differ in nature from those forms of social interaction where definitive relations of sub- or superordination are found. This distinction between social next to each other (coordination) and social super- and subordination reveals the intrinsic coherence between the social and the spatial aspects - they represent analogies of the meaning of space within the meaning of the social aspect. However, in order to understand super- and subordination more fully, the analogy of formative power (control) is needed - i.e. an analogy from the cultural-historical aspect. Legitimate power in the case of human relationships is bound to an office, entailing certain competencies and involving an office-bearer exercising authority over fellow human beings. This is not the only context where the term competence is used - interindividual relations which are on an equal footing presumes a certain social maturity or competence, even if it applies to something like little children playing. This competence for social exchanges constantly requires the ability to correctly interpret the response of other social subjects (analogy of the sign aspect), because without it the mutuality of interaction would become dispirited.

From these examples it is clear that a classification of the different underlying ways of interaction will have to keep in mind the meaning which a particular expression of all analogical structural moments in 
the social aspect acquires. A complete analysis of this would take us into an analysis of the complex (or: composite) basic concepts of sociology as scientific discipline, therefore we just briefly mention the result of such an analysis.

The following two characteristics are important:

- a durable unitary character; and

- a permanent structure of super- and subordination (i.e., of authority).

When a social form of life (lifeform) possesses both a durable unitary character and a permanent authority structure, it may be designated as a social collectivity (in German: Verband). Examples of societal collectivities are the state, the church, business, the school, the university, the (nuclear) family, the art club, the sports club, the cultural club and the language club. The state displays both a durable relation of sub- and superordination (authority of officebearers and those subject to it, i.e. a permanent authority structure), while the unity and identity of a state is not abolished through the coming and going of its citizens (be it office-bearers or subjects). The same applies for all the other societal collectivities that we named in the list of examples.

When a social form of life only displays one of these characteristics, we call it a community. A nation (volk) in the cultural (ethnic) sense of the term and the extended family both possess a durable unitary character (that is why there is continuity between a nation of a hundred years ago and today in spite of changes), but no permanent authority structure can be indicated. In terms of these distinctions neither a state, nor a province, nor a rural town is a community. With reference to the state-side of the given facts, we are working with (higher or lower) forms of governmental authority - and therefore with relations of sub- and superordination which are absent from the communities mentioned in the sense defined above. A city and a town exhibit an interlacement of differently natured societal collectivities, communities and coordinational relationships. ${ }^{13}$

At this point social system theory in all its variants unfortunately fails to appreciate the distinct uniqueness of the multiplicity of social organisations on an equal footing with each other. 
collectivities, communities and coordinational relationships for it adheres to an application of the whole parts relation (systems-subsystems relation) that is originally found in the spatial aspect and then erroneously extended to serve as a basic denominator in terms of which society on the whole could be understood. There are as many options within this holistic (universalistic) legacy as there are distinct societal collectivities or communities. Just consider the three "holy cows" of the West: church, people (ethnic communities) and the state. Each of them suffered from the ideological distortion of being elevated to the encompassing whole of human society, with all the others degraded to mere subordinate parts of the assumed totality.

\section{Sphere-sovereignty}

However, one finds points of connection for an alternative view among some of the most prominent thinkers in the field. In the neofunctionalism of Alexander and Münch the "own inner laws" of differentiated societal spheres of life are acknowledged. According to Münch the starting-point of the theoretical debate of the 1980s is found in "Weber's theory of rationalization of modern society into spheres that are guided to an increasing extent by their own inner laws" (Münch, 1990:442). In particular he mentions the "political system" with "its own inner laws" (Münch, 1990:444). This idea is known as that of sphere-sovereignty. Since Van Prinsterer, Kuyper and Dooyeweerd emphasised that no single societal institution or collectivity ought to be subordinated to any other, they in principle actually took a stance in opposition to the whole-parts scheme (systems and subsystems). Although Rawls (1996) severely struggles with atomism and holism in his thought, he does evince an awareness of the inner nature of distinct societal entities. "But it is the distinct purposes and roles of the parts of the social structure, and how they fit together, that explains there being different principles for distinct kinds of subjects." (Rawls, 1996:262.) On the same page he refers to the distinctive autonomy of elements of society where principles within their own sphere fit their peculiar nature.

This formulation indeed comes close to the idea of spheresovereignty. Indeed, it seems natural to suppose that the distinctive character and autonomy of the various elements of society requires that, within some sphere, they act from their own principles designed to fit their peculiar nature. (Rawls, 1996:262.) 
In a differentiated society various forms of life are institutional in the sense that they bind together individuals for their entire life or just for a part of their lives, independent of their own decisions (such as the state and the nuclear family). Yet not all societal collectivities possess such an institutional character. A business firm, a university or a sport club are all examples of societal collectivities which rest totally on voluntary membership. Yet it is impossible for any person to let his/her life be taken up completely in any of the various societal collectivities and communities in which he/she functions simply because such a person at the same time also takes part in various other interrelations. Two families, for example, stand in a (intercollective) coordinational relationship; two married couples in a (intercommunal) coordinational relationship. Furthermore, every individual is, in a differentiated society, taken up in countless interindividual coordinational relationships where that individual relates informally to fellow human beings in coordinated contexts. Conversely, no person's life is ever completely absorbed in coordinational relationships, because at the opposite side we find institutional and non-institutional communities in which that person is involved. The variety of differentiated, partial, peripheral relationships is therefore nothing more than the multiplicity of social collectivities, communal and coordinational relationships in which human beings are socially involved.

A systematic analysis of the typical totality structure of social entities is found in the third volume of the magnum opus of Dooyeweerd (cf. 1997-3) where he develops the idea of the foundational and qualifying functions of social collectivities and communities. The perspectives opened-up in this analysis successfully integrates the challenge of multidisciplinary perspectives on social systems while at the same time arguing for a perspective transcending the shortcomings inherent in atomistic and holistic approaches to human society. This view includes a distinction between modal laws and type laws, 14 but an exploration of these distinctions exceeds the confines of this article. Its purpose was merely to highlight the inevitability of explicitly accounting for the basic concepts (elementary, complex and typical) of a scientific reflection on human society, against the background of societal practices and theoretical approaches (mainly 
in the grip of the modern humanistic motive of nature and freedom). 15

The global world in which we live needs developments enhancing a further differentiation of accountable responsibilities - for fellow human beings and for our planet, unless it wants to derail into a path of dedifferentiation, torn apart by the tensions between the scienceideal and the personality ideal, modernity and postmodernity, atomism and holism.

\section{List of references}

ALEXANDER, J.C. 1987. Sociological theory since World War 2: twenty lectures. New York: Columbia University Press.

ALEXANDER, J.C. 1988. Action and its environments. New York: Columbia University Press.

ARISTOTLE 1894. Politica. (In Susemihl, F. \& Hicks, R.D., ed. The politics of Aristotle: a revised text. New York: McMillan. p. 138-560.)

BEHE, M.J. 2003. Darwin's black box. New York: The Free Press.

DOOYEWEERD, H. 1997. A new critique of theoretical thought. General editor: D.F.M. Strauss. Lewiston: Edwin Mellen. (Collected Works of Herman Dooyeweerd. A-Series, vols. 1-4.)

FLETCHER, R. 1971. The making of sociology. Vol. 1: Beginnings and foundations. London: Nelson.

HOBBES, Th. 1968 [1651]. Leviathan. Harmondsworth: Pelican.

HOLLINGER, R. 1994. Postmodernism and the social sciences. London: Sage.

HUSSERL, E. 1954. Die Krisis der europäischen Wissenschaften und die transzendentale Phänomenologie. The Hague: Nijhoff. (Husserliana, Band 6.)

LAUGWITZ, D. 1986. Zahlen und Kontinuum: eine Einführung in die Infinitesimalmathematik. Mannheim: B.I.-Wissenschafsverlag.

LOTTER, M-S. 2000. Das individuele Gesetz: zu Simmil's Kritik an der Lebensfremdheit der kantischen Moralphilosophie. Kant-studien, 2:178203.

MÜNCH, R. 1990. Differentiation, rationalisation, interpenetration: the emergence of modern society. (In Alexander, J.C. Differentiation theory and social change. Co-editor: Paul Colomy. New York: Columbia University Press. p. 441-464.)

PLATO. 1966. The republic. Transl. by F.M. Cornford. Oxford: Clarendon.

PORTMANN, A. 1974. An den Grenzen des Wissens, von Beitrag der Biologie zu einem neuen Weltbild. Wien: Econ.

PORTMANN, A. 1990. A zoologist looks at humankind. Transl. by Judith Schaefer. New York: Columbia University Press.

15 A systematic analysis of the elementary and complex basic concepts of sociology as a discipline is found in Strauss (2006). 
RAWLS, J. 1996. Political liberalism. Revised ed. Cambridge: Harvard University Press.

SCHUURMAN, E. 2008. Technology and the future. 2nd ed. Jordan Station: Paideia.

SIMPSON, G.G. 1969. Biology and man. New York: Harcourt.

STEGMÜLLER, W. 1987. Hauptströmungen der Gegenwartsphilosophie. Bd. 3. Stuttgart: Kröner.

STRAUSS, D.F.M. 2006. Reintegrating social theory - reflecting upon human society and the discipline of sociology. Frankfurt: Lang.

STRAUSS, D.F.M. 2007. Did Darwin develop a theory of evolution in the biological sense of the word? South African journal of philosophy, 26(2):190-203.

SUSSENBACH, J.S. 2005. Celdeling en de synthese van DNA: evolutie of ontwerp. (In Dekker, C., Meester, R. \& Van Woudenberg, R. Schitterend ongeluk of sporen van ontwerp? Kampen: Ten Have. p. 134-143.)

VAN RIESSEN, H. 1952. The society of the future. Philadelphia: The Presbyterian and Reformed Publishing Company.

VON BERTALANFFY, L. 1973. General system theory. Hammondsworth: Penguin.

WATERS, M. 1994. Modern sociological theory. London: Sage.

WIENER, N. 1950. Cybernetics: or control and communication in the animal and the machine. New York: lley.

WIENER, N. 1954. The human use of human beings, cybernetics and society. London: Eyre \& Spottiswoode.

WIENER, N. 1956. Why I am a mathematician. New York: Doubleday.

WIENER, N. 1964. God and Golem. Cambridge: The Riverside.

\section{Key concepts:}

atomism

holism

personality ideal

science ideal

social collectivities: community relationships

sovereignty

\section{Kernbegrippe:}

atomisme

holisme

persoonlikheidsideaal

soewereiniteit in eie kring

verbande: gemeenskapsverhoudings

wetenskapsideaal 
